\title{
Phylogenetic Characterization of Tomato chlorosis virus Population in Korea: Evidence of Reassortment between Isolates from Different Origins
}

\author{
Ye-Ji Lee ${ }^{1,2,3 \dagger}$, Eui-Joon Kil ${ }^{1 \dagger}$, Hae-Ryun Kwak ${ }^{3}$, Mikyeong Kim ${ }^{3}$, Jang-Kyun Seo ${ }^{3,4}$, Sukchan Lee ${ }^{1 *}$, and \\ Hong-Soo Choi $^{3 *}$ \\ ${ }^{1}$ Department of Genetic Engineering, Sungkyunkwan University, Suwon 16419, Korea \\ ${ }^{2}$ Dapartment of Seed Services, Foundation of Agricultural Technology Commercialization and Transfer, Iksan 54667, \\ Korea \\ ${ }^{3}$ Crop Protection Division, National Academy of Agricultural Science, Rural Development Administration, Wanju \\ 55365, Korea \\ ${ }^{4}$ Graduate School of International Agricultural Technology, Seoul National University, Pyeongchang 25354, Korea
}

(Received on October 24, 2017; Revised on January 22, 2018; Accepted on February 16, 2018)

Tomato chlorosis virus (ToCV) is a whitefly-transmitted and phloem-limited crinivirus. In 2013, severe interveinal chlorosis and bronzing on tomato leaves, known symptoms of ToCV infection, were observed in greenhouses in Korea. To identify ToCV infection in symptomatic tomato plants, RT-PCR with ToCV-specific primers was performed on leaf samples collected from 11 tomato cultivating areas where ToCV-like symptoms were observed in 2013 and 2014. About half of samples $\mathbf{( 4 5 . 1 8 \% )}$ ) were confirmed as ToCV-infected, and the complete genome of $\mathbf{1 0}$ different isolates were characterized. This is the first report of ToCV occurring in Korea. The phylogenetic relationship and genetic variation among ToCV isolates from Korea and other countries were also analysed. When RNA1 and RNA2 are analysed separately, ToCV isolates were clustered into three groups in phylogenetic trees, and ToCV Korean isolates were confirmed to belong to two groups, which

\footnotetext{
${ }^{\dagger}$ These authors contributed equally to this work as first authors.

*Co-corresponding authors.

H-S Choi

Phone) +82-63-238-3298, FAX) +82-63-238-3811

E-mail)hschoi@korea.kr

S Lee

Phone) +82-31-290-7866, FAX) +82-31-290-7892

E-mail) cell4u@skku.edu

(c) This is an Open Access article distributed under the terms of the Creative Commons Attribution Non-Commercial License (http:// creativecommons.org/licenses/by-nc/4.0) which permits unrestricted noncommercial use, distribution, and reproduction in any medium, provided the original work is properly cited.
}

Articles can be freely viewed online at www.ppjonline.org. were geographically separated. These results suggested that Korean ToCV isolates originated from two independent origins. However, the RNA1 and RNA2 sequences of the Yeonggwang isolate were confirmed to belong to different groups, which indicated that ToCV RNA1 and RNA2 originated from two different origins and were reassorted in Yeonggwang, which is the intermediate point of two geographically separated groups.

Keywords : Crinivirus, reassortment, Tomato chlorosis virus

Handling Associate Editor : Lim, Hyoun-Sub

Tomato chlorosis disease is one of the most devastating diseases in tomato crop production (Hanssen et al., 2010). The chlorotic leaf symptom of tomatoes was observed in Florida in 1989, and the virus responsible was first named Tomato chlorosis virus (ToCV) in the USA (Wisler et al., 1998b). Subsequently, this virus has been distributed to many parts of the world including European, American, African and Asian countries (Abou-Jawdah et al., 2006; Accotto et al., 2001; Alvarez-Ruiz et al., 2007; Arruabarrena et al., 2015; Barbosa et al., 2008; Bese et al., 2011; Castro et al., 2009; Çevik and Erk1ß, 2008; Dalmon et al., 2005; Dovas et al., 2002; Fiallo-Olivé et al., 2011; Hirota et al., 2010; Jacquemond et al., 2009; Lett et al., 2009; Louro et al., 2000; Segev et al., 2004; Sundaraj et al., 2011; Wintermantel et al., 2001; Wintermantel and Wisler, 2006; Zhao et al., 2013a). In northeast Asia, ToCV occurrence was originally reported in China, Taiwan and Japan (Hirota et al., 2010; Tsai et al., 2004; Zhao et al., 2013b), but was 
not reported in Korea until 2013. ToCV is a species of the genus Crinivirus that belongs to the family Closteroviridae with flexuous filamentous particles of approximately 800 to $850 \mathrm{~nm}$ in length (Liu et al., 2000; Wisler et al., 1998b). ToCV is usually phloem-limited and is transmitted by whiteflies (Bemisia and Trialeuroides spp.) in a semipersistent manner (Karasev, 2000; Wisler et al., 1998a). Mechanical inoculation and seed transmission have not been demonstrated. The genome consist of two segments of linear, positive-sense and single-stranded RNA, which are separately encapsidated (Wisler et al., 1998b; Wintermantel et al., 2005; Zhao et al., 2014). The size of ToCV RNAs 1 and 2 is 8595nt and 8247nt, respectively. RNA1 contains four open reading frames (ORFs), which encode proteins for replication. RNA2 codes nine ORFs that express proteins involved in viral encapsidation, movement and vector transmission (Wintermantel et al., 2005).

In tomato, ToCV causes interveinal yellowing that can be observed first on lower leaves and subsequent development of leaf thickening, bronzing and necrotic flecks on the older leaves (Wisler et al., 1998b; Wintermantel et al., 2005). Theses typical patterns gradually proceed toward the growing point. Although no obvious fruit symptoms have been observed, crop yield can be significantly reduced due to the loss of photosynthetic area (Wintermantel et al., 2005). Symptoms caused by ToCV are easily confused with those caused by physiological or nutritional deficiency and are very similar to those of other whitefly-transmitted viruses such as Tomato infectious chlorosis virus (TICV) (Wisler et al., 1998b). So, infection of tomato plants with these viruses is difficult to diagnose based on symptoms. In addition to tomatoes, potato (Solanum tuberosum), sweet pepper (Capsicum annuum) and zinnia (Zinnia elegans) are known ToCV hosts (Barbosa et al., 2010; Fortes and Navas-Castillo, 2012; Lozano et al., 2004; Tsai et al., 2004; Vargas et al., 2011). In total, about 36 species of plants have also been reported as ToCV hosts (Alvarez-Ruiz et al., 2007; Barbosa et al., 2010; Font et al., 2004; Fortes and Navas-Castillo, 2012; Lozano et al., 2004; Morris et al., 2006; Segev et al., 2004; Solórzano-Morales et al., 2011; Trenado et al., 2007; Tsai et al., 2004; Wintermantel and Wisler, 2006; Vargas et al., 2011).

Genetic exchanges through reassortment and recombination are major evolutionary factors for RNA plant viruses (Aranda et al., 1997; Domingo and Holland, 1994; Nagy, 2008; Simon and Bujarski, 1994), that can result in differences in symptom severity, host range, or transmission efficiency of plant viruses (Thekke-Veetil et al., 2015). Virus reassortment is a process of genetic recombination for multipartite (segmented) RNA viruses that occurs in host cells co-infected with multiple viruses and generates hybrid progeny viruses with novel genome combinations (Marshall et al., 2013; Vijaykrishna et al., 2015). Despite the importance of reassortment for plant viruses that can affect the production of economically important crops, many related studies on virus reassortment have focused on influenza virus and other viruses infecting humans or animals (Barton et al., 2014; Fuller et al., 2013; Savory et al., 2014; Wille et al., 2011).

In this study, we report the viral genome sequences of $10 \mathrm{ToCV}$ isolates obtained from Korea, and present results of phylogenetic analyses among these isolates and ToCV isolates from other countries that provide evidence of reassortment of two viral segments originating from two geographically separated groups.

\section{Materials and Methods}

Sample collection, total RNA extraction and RTPCR. In 2013 and 2014, a total of 394 samples of tomato leaves showing interveinal chlorosis and bronzing were collected from 11 tomato cultivation areas (Yeoju, Gwangju, Nonsan, Iksan, Yeonggwang, Hwasun, Hampyeong, Jeju, Seogwipo, Pyeongtaek and Buyeo) (Fig. 1, Table 1). ToCV-specific primers were designed based on the viral genome sequence of isolate Gr-535 RNA2 (EU284744.1) retrieved from the GenBank database using the Primer3 program (Rozen and Skaletsky, 2000). The primer sequences were as follows: ToCV-RNA2-1F (5'ACCTTGGCAGGTTGTGAAAC-3') and ToCV-RNA21R (5'-CGATATCTGGTGGGAGGCTA-3'). Total RNA was extracted from leaf samples using Viral Gene-spin ${ }^{\mathrm{TM}}$ Viral DNA/RNA Extraction Kit (iNtRON Biotechnology, Seongnam, Korea). cDNA was synthesised from extracted total RNA using AMV Reverse Transcriptase (Promega,
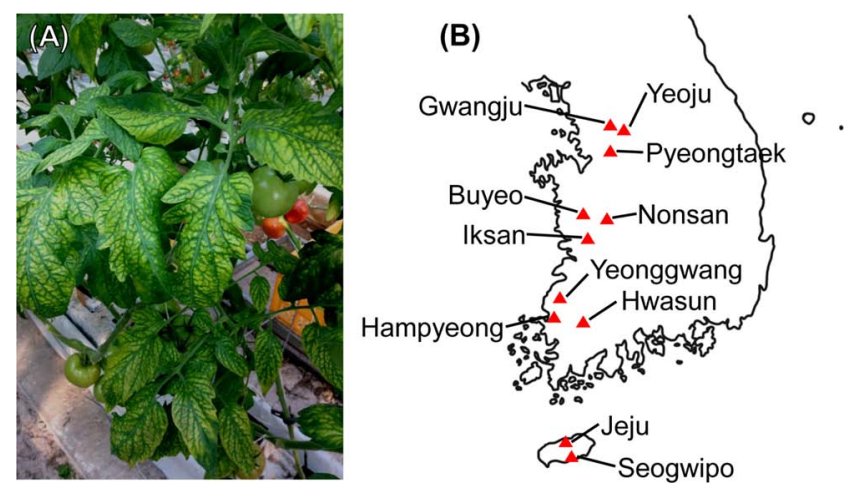

Fig. 1. Occurrence of ToCV in Korea. (A) Symptomatic tomato leaves from Iksan showing interveinal leaf chlorosis. (B) Geographic locations of sampling sites. 
Table 1. Infection prevalence of ToCV in collected tomato samples

\begin{tabular}{|c|c|c|c|c|c|}
\hline \multirow{2}{*}{ Years } & \multirow{2}{*}{ Provinces } & \multirow{2}{*}{ Region } & \multicolumn{2}{|c|}{ Number of sample(s) } & \multirow{2}{*}{$\begin{array}{c}\text { Infection prevalence } \\
\qquad(\%)\end{array}$} \\
\hline & & & Collected & ToCV-infected & \\
\hline \multirow[t]{9}{*}{2013} & Gyeonggi-do & Yeoju & 2 & 1 & 50 \\
\hline & & Gwangju & 1 & 1 & 100 \\
\hline & Chungcheongnam-do & Nonsan & 3 & 3 & 100 \\
\hline & Jeollabuk-do & Iksan & 43 & 41 & 95.35 \\
\hline & Jeollanam-do & Yeonggwang & 13 & 10 & 76.92 \\
\hline & & Hwasun & 19 & 15 & 78.95 \\
\hline & & Hampyeong & 29 & 7 & 24.14 \\
\hline & Jeju-do & Jeju & 63 & 20 & 31.75 \\
\hline & & Seogwipo & 65 & 26 & 40.00 \\
\hline \multirow[t]{7}{*}{2014} & Gyeonggi-do & Pyeongtaek & 5 & 2 & 40.00 \\
\hline & Chungcheongnam-do & Buyeo & 30 & 1 & 3.33 \\
\hline & Jeollabuk-do & Iksan & 95 & 37 & 38.95 \\
\hline & Jeollanam-do & Hwasun & 1 & 1 & 100.00 \\
\hline & Jeju-do & Jeju & 13 & 9 & 69.23 \\
\hline & & Seogwipo & 12 & 4 & 33.33 \\
\hline & Total & & 394 & 178 & 45.18 \\
\hline
\end{tabular}

Madison, WI, USA) and ToCV specific primer (ToCVRNA2-1R). PCR was conducted using a ToCV-specific primer set (ToCV-RNA2-1F and ToCV-RNA2-1R) and $\mathrm{GoTaq}^{\circledR}$ Flexi DNA Polymerase (Promega) in a $\mathrm{T} 100^{\mathrm{TM}}$ thermal cycler (Bio-Rad, Hercules, CA, USA) under the following conditions: initial denaturation at $95^{\circ} \mathrm{C}$ for $3 \mathrm{~min}$; 35 cycles of $30 \mathrm{~s}$ at $94^{\circ} \mathrm{C}, 30 \mathrm{~s}$ at $55^{\circ} \mathrm{C}$, and $1 \mathrm{~min}$ at $72^{\circ} \mathrm{C}$; and a final extension step at $72^{\circ} \mathrm{C}$ for $5 \mathrm{~min}$. The expected size of the RT-PCR product is $827 \mathrm{bp}$.

Full-length genome sequencing of the ToCV Korean isolates. To determine full-length nucleotide sequences, RT-PCR was performed with primers designed based on the previously reported ToCV sequences (GenBank accession numbers: AY903447.1 and KJ815045.1) (Table 2). Viral genome amplification was conducted using LA Taq DNA polymerase (Takara, Tokyo, Japan) in a T100 ${ }^{\mathrm{TM}}$ thermal cycler (Bio-Rad) under the following conditions: initial denaturation at $95^{\circ} \mathrm{C}$ for $3 \mathrm{~min} ; 35$ cycles of $30 \mathrm{~s}$ at $94^{\circ} \mathrm{C}, 30 \mathrm{~s}$ at $55^{\circ} \mathrm{C}$ and $3 \mathrm{~min}$ at $72^{\circ} \mathrm{C}$; and a final extension step at $72^{\circ} \mathrm{C}$ for $5 \mathrm{~min}$. Full-length nucleotide sequences of RNA1 and RNA2 were acquired by combining three overlapping RT-PCR products (Fig. 2). Rapid amplification of cDNA ends (RACE) was performed to determine the 5' and 3' ends of the viral genomic segments. The amplified PCR products were purified using the QIAquick PCR purification kit (Qiagen, Hilden, Germany) and sequenced (Macrogen, Seoul, Korea).
Sequence analysis. Full genome sequences were assembled using the DNASTAR software (DNASTAR, Madison, WI, USA) and compared by a BLAST search (https:// blast.ncbi.nlm.nih.gov) with previously reported sequences in the GenBank database (Johnson et al., 2008). Identification of open reading frames was performed by the ORF Finder (https://www.ncbi.nlm.nih.gov/orffinder).

Complete sequences of the $10 \mathrm{ToCV}$ isolates from Korea and eight previously reported isolates was used to examine population genetics. The nucleotide sequences were aligned using the Clustal $\mathrm{X}$ and DNAstar programs (Thompson et al., 2002). Phylogenetic analyses of the complete genome sequences were performed by the maximum likelihood method implemented in the MEGA6 program (Tamura et al., 2013). Statistical significance of tree branching was assessed by performing 1000 bootstrap replications. The Geneious software (Biomatters, Auckland, New Zealand) was used to analyse nucleotide identities (Kearse et al., 2012). Pairwise genetic distances was analysed by Kimura's twoparameter method using the MEGA6 program (Kimura, 1980; Tamura et al., 2013). Database accession numbers and the complete sequences for the isolates used in the phylogenetic and similar analyses in this study are shown in Table 3.

\section{Results and Discussion}

Outbreak of viral infection in tomato plants in Korea. 
Table 2. Primer sets for ToCV full-length genome sequencing

\begin{tabular}{|c|c|c|}
\hline Primers & Sequences $\left(5^{\prime}-3^{\prime}\right)$ & Target region \\
\hline \multicolumn{3}{|l|}{ RNA1 } \\
\hline \multicolumn{3}{|l|}{ For RACE } \\
\hline ToCV-R1-5'RV & GTTCATGCGAGTTTTTATCC & $407-426$ \\
\hline $\mathrm{Xec}$ & AAAGAATTCCCCССССССССC & \\
\hline ToCV-RNA1-3'3f & TAAAGTAATCATCAGAGTGTATC & $7950-7972$ \\
\hline ToCV-RNA1-3'1r & TTTTTTTTTTTTTTCGACCTATTTATTTA & \\
\hline \multicolumn{3}{|c|}{ For reverse transcription $(\mathrm{RT})$} \\
\hline ToCV-R1-1r & ACATTTCACGAACGCATTTC & $3671-3690$ \\
\hline ToCV-R1-2r & ATACTGTCCGGTCTCGTCC & $6404-6422$ \\
\hline ToCV-R1-3r & CCAAAGGAAGGAAACATTATCA & $8428-8449$ \\
\hline \multicolumn{3}{|c|}{ For RT-PCR and sequence analysis } \\
\hline ToCV-R1-1F & GTTCAGTGTCGACCTTATCA & $94-113$ \\
\hline ToCV-R1-1R & GCCССТTCATCTCTTTAGCA & $3482-3501$ \\
\hline ToCV-R1-2F & CGATCCTCGGTGATTCTATC & $3070-3089$ \\
\hline ToCV-R1-2R & AAACTCCCCTGCGACATAAG & $6353-6372$ \\
\hline ToCV-R1-3F & CAGTCCGGATGTGAAGATGA & $5801-5820$ \\
\hline ToCV-R1-3R & CCACCTAAAATGACCTGACC & $8192-8211$ \\
\hline \multicolumn{3}{|l|}{ For sequence analysis } \\
\hline ToCV-R1-1u & TTCTCTGTGGTGTGATAGTTTC & $899-920$ \\
\hline ToCV-R1-1d & TTCTTGGCCCTGTACTGA & $2681-2698$ \\
\hline ToCV-R1-2u & TTGGATGCGTTATCACTCTA & $3356-3375$ \\
\hline ToCV-R1-2d & GGCATCACTCAAAAGAAGAC & $4738-4757$ \\
\hline ToCV-R1-3u & GTGGCTGACGATTCTATTTC & $4629-4648$ \\
\hline ToCV-R1-3d & GCAACCTTATCCAAAGATGA & $6078-6097$ \\
\hline ToCV-R1-4u & GAGACCGGACAGTATGAAAC & $6408-6427$ \\
\hline ToCV-R1-4d & GCACGTTGTATCGTAATCAA & $7493-7512$ \\
\hline \multicolumn{3}{|l|}{ RNA2 } \\
\hline \multicolumn{3}{|l|}{ For RACE } \\
\hline ToCV-R2-5'R & CCGACTTCGAAAGTGCAGAG & $395-414$ \\
\hline $\mathrm{Xec}$ & AAAGAATTCСССССССССССС & \\
\hline ToCV-RNA2-3'2f & GTGAAATTGACAGAAGGTTGAGTA & $7659-7682$ \\
\hline ToCV-RNA2-3'2r & TTTTTTTTTTTTTCGAGGTATTTATTTAT & \\
\hline \multicolumn{3}{|c|}{ For reverse transcription } \\
\hline ToCV-R2-1r & GTCAGTTGTGCAGTCGGTTC & $3017-3036$ \\
\hline ToCV-R2-2r & TGACGTAATCCCCAACCAA & $5579-5597$ \\
\hline ToCV-R2-3r & CGAAGTAAATAACCCGAAGAAG & $8094-8115$ \\
\hline \multicolumn{3}{|c|}{ For RT-PCR and sequence analysis } \\
\hline ToCV-R2-1F & TAATTACCCCACCGTCACTA & $53-72$ \\
\hline ToCV-R2-1R & TTGTGCAGTCGGTTCTTCAC & $3012-3031$ \\
\hline ToCV-R2-2F & GAGTCATGGAACCCGTTGATA & $2559-2579$ \\
\hline ToCV-R2-2R & AACCATCCAGAAAGTCTCAC & $5354-5373$ \\
\hline ToCV-R2-3F & AGGTTAGACCCAAAATGTCC & $4804-4823$ \\
\hline ToCV-R2-3R & AAACCTGTTACTCCCGAATG & $7985-8004$ \\
\hline \multicolumn{3}{|l|}{ For sequence analysis } \\
\hline ToCV-R2-1u & ACATTCCAACTTGTCTCTCC & $835-854$ \\
\hline ToCV-R2-1d & TTGCCAGTGGTTTTATTAGC & $2130-2149$ \\
\hline ToCV-R2-2u & CAAAAACTGATAACGCTGAA & $3123-3142$ \\
\hline ToCV-R2-2d & TCTTCTCGAACTCСТСТTCC & $4586-4605$ \\
\hline ToCV-R2-3u & TTTACCTAACCCGAGTCTGA & $5647-5666$ \\
\hline ToCV-R2-3d & AATTGTACACGACCTCCATC & $7126-7145$ \\
\hline
\end{tabular}



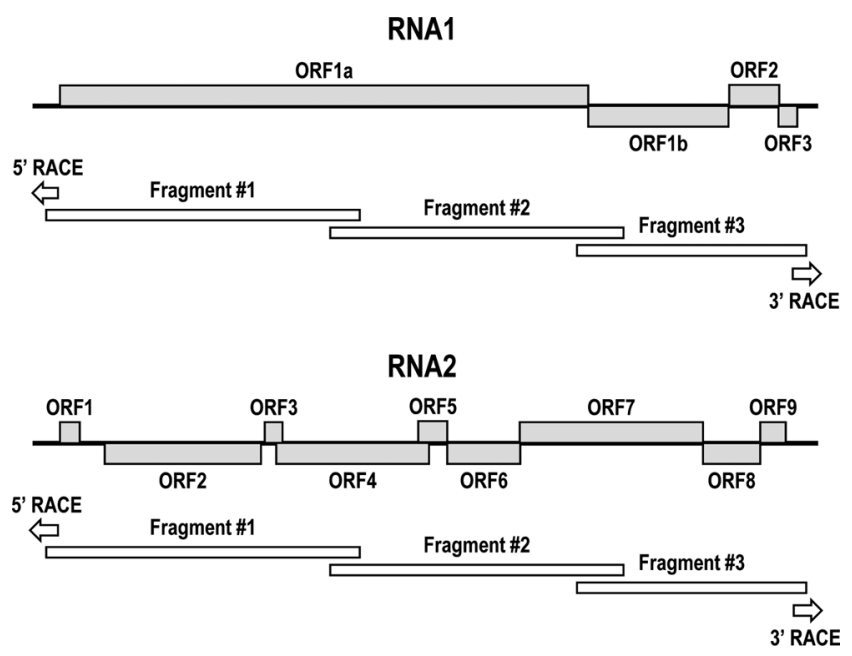

Fig. 2. Schematic diagram of RT-PCR-based strategy for fulllength genome sequencing of ToCV.

In January 2013, tomato plants showing virus-like symptoms of yellowing, bronzing, and chlorosis on lower leaves was found in Iksan, Korea (Fig. 1). Total RNAs were then extracted from all samples and tested by RT-PCR using ToCV specific primers. ToCV-specific amplicons were detected from symptomatic samples in Iksan. To examine distribution and occurrence pattern of $\mathrm{ToCV}$, during the period from 2013 to 2014, a total of 394 samples of symptomatic tomatoes were collected 11 tomato cultivation regions in Korea. Among the 394 samples, 178 were found to be infected with ToCV based on RT-PCR analysis (Table 1). RT-PCR products were sequenced, and BLAST results showed a high sequence identity $(>97 \%)$ with previously reported ToCV isolates. Most samples (79.2\%) infected with ToCV were co-infected with TYLCV, which showed 99-100\% similarity to previously reported sequence of a Korean isolate (GenBank accession number: JN680149.1).

Molecular characterization of Korean ToCV isolates. To examine molecular genetic structure of ToCV population in Korea, the complete nucleotide sequences of 10 ToCV Korean isolates identified in 2013 (except for isolates from Yeoju and Gwangju areas where only one individual was identified) were determined and deposited to the GenBank database (GenBank accession numbers are provided in Table 3). Comparison of the complete nucleotide sequences of the ToCV Korean isolates with all ToCV isolates available on the NCBI database showed overall sequence identities ranging from 97.4 to $99.7 \%$ for RNA1 and from 97.5 to $99.7 \%$ for RNA2 (data not shown). ToCV RNA1 consisted of four open reading frames (ORFs), as previously reported, and the complete genomic sequences of RNA2 of the ToCV Korean isolates were confirmed as containing nine ORFs (Fig. 2).

Genetic structure of the ToCV population. The MEGA

Table 3. ToCV isolates analyzed in this study

\begin{tabular}{|c|c|c|c|c|c|}
\hline \multirow{2}{*}{ Virus isolates } & \multirow{2}{*}{ Countries } & \multirow{2}{*}{ Years } & \multicolumn{2}{|c|}{ GenBank accession no. } & \multirow{2}{*}{ References } \\
\hline & & & RNA1 & RNA2 & \\
\hline ToCV_Florida1 & USA & 2005 & NC_007340.1 & NC_007341.1 & Wintermantel et al., 2005 \\
\hline ToCV_Florida2 & USA & 2005 & AY903447.1 & AY903448.1 & Wintermantel et al., 2005 \\
\hline ToCV_ToC-Br2 & Brazil & 2006 & JQ952600.1 & JQ952601.1 & Albuquerque et al., 2012 \\
\hline ToCV_AT80/99 & Spain & 2006 & DQ983480.1 & DQ136146.1 & Lozano et al., 2006 \\
\hline ToCV_Gr-535 & Greece & 2008 & EU284745.1 & EU284744.1 & Kataya et al., 2008 \\
\hline ToCV_BJ & China & 2013 & KC887998.1 & KC887999.1 & Zhao et al., 2013a \\
\hline ToCV_SDSG & China & 2013 & KC709509.1 & KC709510.1 & Zhao et al., 2015 \\
\hline ToCV_AT80/99-IC & Spain & 2014 & KJ740256.1 & KJ740257.1 & Orílio et al., 2014 \\
\hline ToCV_JJ3 & Korea (Jeju) & 2013 & KP114532.1 & KP114533.1 & This study \\
\hline ToCV_JJ5 & Korea (Jeju) & 2013 & KP114527.1 & KP114534.1 & This study \\
\hline ToCV_IS17 & Korea (Iksan) & 2013 & KP114535.1 & KP114525.1 & This study \\
\hline ToCV_IS29 & Korea (Iksan) & 2013 & KP114538.1 & KP114529.1 & This study \\
\hline ToCV_HS & Korea (Hwasun) & 2013 & KP137098.1 & KP137099.1 & This study \\
\hline ToCV_HP & Korea (Hampyeong) & 2013 & KP114530.1 & KP114537.1 & This study \\
\hline ToCV_YG & Korea (Yeonggwang) & 2013 & KP114526.1 & KP114528.1 & This study \\
\hline ToCV_JN1 & Korea (Yeonggwang) & 2013 & KP114531.1 & KP114536.1 & This study \\
\hline ToCV_JN2 & Korea (Yeonggwang) & 2013 & MG813909.1 & MG813910.1 & This study \\
\hline ToCV_NS & Korea (Nonsan) & 2013 & MG813908.1 & MG813911.1 & This study \\
\hline
\end{tabular}


(A)

RNA1

(B)

RNA2
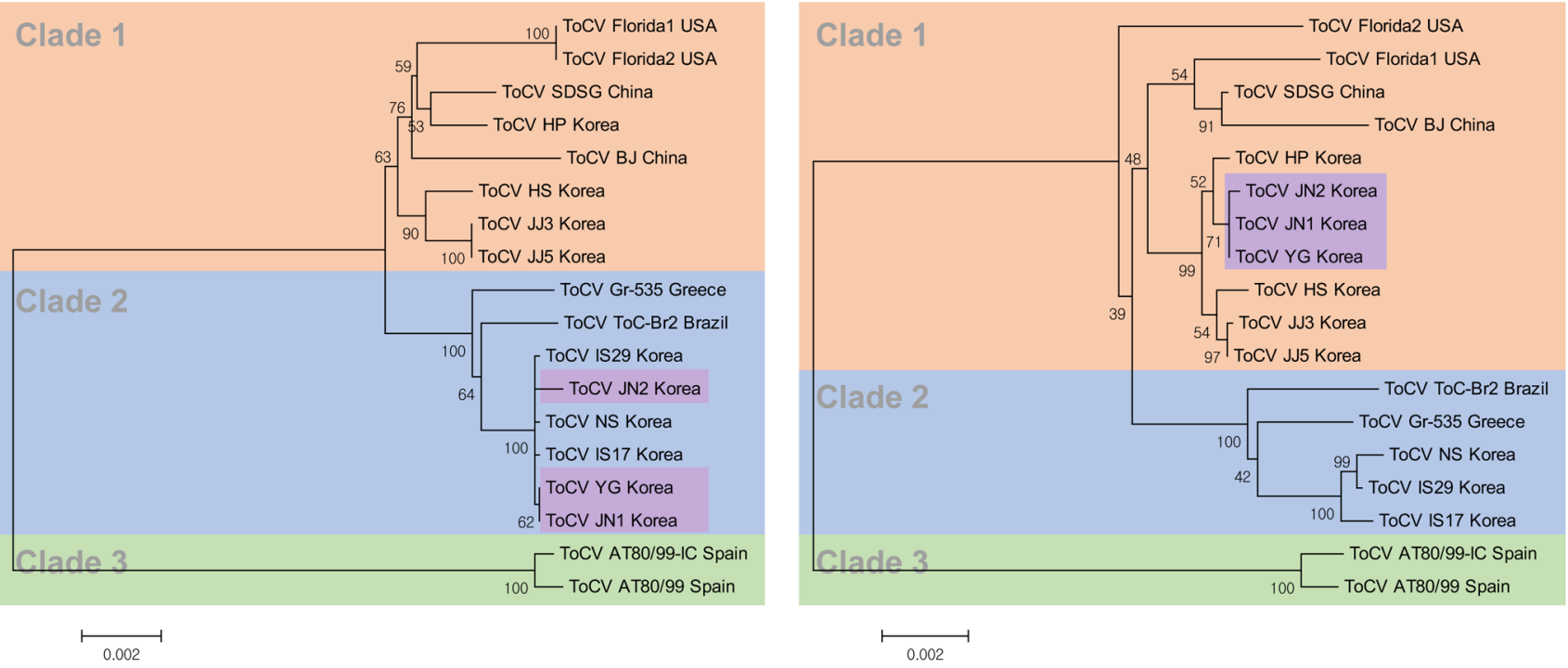

Fig. 3. Molecular Phylogenetic analysis of ToCV RNA1 (A) and RNA2 (B) using the maximum likelihood method. The evolutionary history was inferred by using the maximum likelihood method based on the Tamura-Nei model (Tamura and Nei, 1993). The percentage of trees in which the associated taxa clustered together is shown next to the branches. Initial tree(s) for the heuristic search were obtained automatically by applying Neighbor-Join and BioNJ algorithms to a matrix of pairwise distances estimated using the Maximum Composite Likelihood (MCL) approach and then selecting the topology with superior log likelihood value. The tree is drawn to scale, with branch lengths measured in the number of substitutions per site. The analysis involved 18 nucleotide sequences. Codon positions included were $1 \mathrm{st}+2 \mathrm{nd}+3 \mathrm{rd}+$ Noncoding. All positions containing gaps and missing data were eliminated. Evolutionary analyses were conducted in MEGA6 (Tamura et al., 2013). ToCV isolated were grouped into three clades [clade 1 (red), 2 (blue) and 3 (green)] and two segments (RNA1 and RNA2) belonged to different clades in the case of isolates JN1, JN2 and YG (purple).

6.0 program was used to construct a phylogenetic tree using 10 complete sequences determined in this study and eight complete sequences retrieved from the GenBank database (Table 2). Phylogenetic trees constructed using the full-length nucleotide sequences of ToCV RNA1 and RNA2 revealed that the ToCV isolates could be clustered

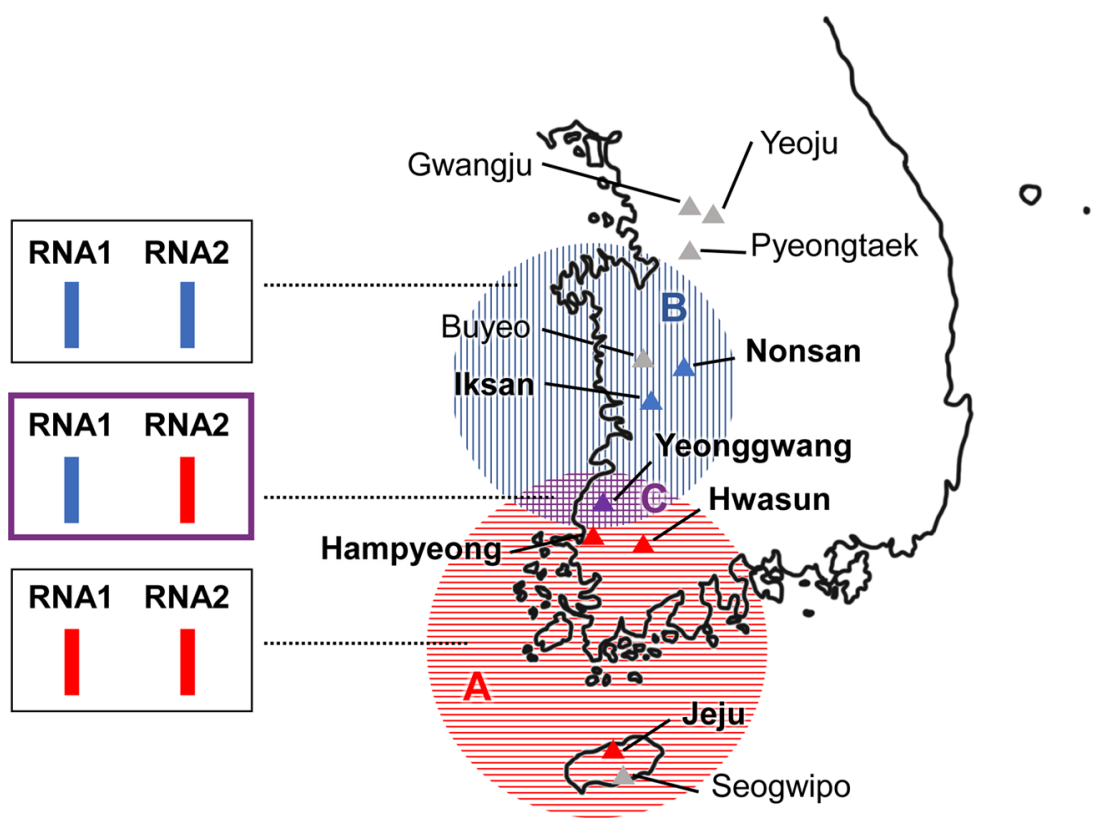

Fig. 4. Geographic distribution of ToCV isolates in Korea. ToCV isolates from tomato were clustered into three subpopulations based on the phylogenetic analysis. 
Table 4. Genetic diversity of population of ToCV RNA1 and RNA2. Analyses were conducted using the Kimura 2-parameter model (Kimura, 1980). The analysis involved three clades. Evolutionary analyses were conducted in MEGA6 (Tamura et al., 2013)

\begin{tabular}{cccc}
\hline & \multicolumn{3}{c}{ Nucleotide diversity between subpopulations $^{\mathrm{b}}$} \\
\cline { 2 - 4 } Population $^{\mathrm{a}}$ & Clade 1 & Clade 2 & \\
\hline RNA1 & & & \\
Clade 1 & $0.00196 \pm 0.00027$ & $0.00156 \pm 0.00027$ & $0.00496 \pm 0.00056$ \\
Clade 2 & $0.00603 \pm 0.00097$ & $0.00507 \pm 0.00056$ & \\
Clade 3 & $0.00750 \pm 0.00087$ & & \\
RNA2 & & & $0.00100 \pm 0.00026$ \\
Clade 1 & $0.00412 \pm 0.00047$ & $0.00535 \pm 0.0066$ & $0.00472 \pm 0.00064$ \\
Clade 2 & $0.00741 \pm 0.00088$ & & \\
Clade 3 & $0.00864 \pm 0.00086$ & & \\
\hline
\end{tabular}

${ }^{a}$ Subpopulations were designated based on the phylogenetic trees shown in Fig. 3.

${ }^{b}$ Numeric values indicate nucleotide diversity \pm standard error.

into three groups (Fig. 3). Our results suggested that the ToCV isolates from Jeju, Hwasun, and Hampyeong belong to the same group as isolates from Greece and Brazil (Clade 1), whereas the isolates from Iksan and Nonsan were similar to the isolates from the USA and China (Clade 2) (Fig. 3). In particular, for the isolates from Yeonggwang (ToCVYG, JN1 and JN2), RNA1 was closer to the isolates from the USA and China in Clade 2 than those from Greece and Brazil, whereas RNA2 showed the opposite tendency, with these isolates in Clade 1 (Fig. 3, 4). From a geographical point of view, the isolates collected from northern areas of Yeonggwang belonged to group 1, while those from the southern area of Iksan were included in group 2 (Fig. 4). This clustering of the ToCV population was further supported by nucleotide diversity analyses. The genetic diversities within and between subpopulations, which were designated based on the phylogenetic trees, were estimated by Kimura's two-parameter method (Kimura, 1980). The analyses showed that the genetic diversities within subpopulations were somewhat lower compared with those between subpopulations (Table 4). Although ToCV is an RNA virus, population analyses of the ToCV isolates showed high conservation and low molecular variation among the isolates. However, the concatenated sequences of entire genomes (i.e., RNA1 + RNA2) of ToCV isolates strictly indicate that reassortment (Table 4, Fig. 3). Genetic reassortment is an important evolutionary event in the diversification of RNA viruses.

In this study, it is confirmed that ToCV isolates in Korea are grouped into two clades based on the phylogenetic analyses. This clustering makes it possible to hypothesize that the ToCV isolates found in Korea have at least two different origins, which can be separated geographically. However, this hypothesis cannot be proven only by the clues provided in this study. In order to prove this, it is necessary to obtain information on the inflow of viruliferous whitefly or ToCV infected plants at the early stage of virus occurrence, but it is not easy to confirm this.

We also found that genetic exchanges have occurred by segment reassortment in natural ToCV populations. Phylogenetic analyses of three Korean isolates (ToCV YG, JN1 and JN2) provided a significant clue to reassortment between two different groups. This means that another ressortment inducing more severe economic damage may occur when ToCV strain(s) that differ from those previously reported arise and are introduced.

\section{Acknowledgments}

This research was supported by a grant from the Agenda Program (PJ012013) funded by the Rural Development Administration of Korea and a fund (Project Code No. Z-1543086-2017-21-01) by Research of Animal and Plant Quarantine Agency, South Korea.

\section{References}

Abou-Jawdah, Y., El Mohtar, C., Atamian, H. and Sobh, H. 2006. First report of Tomato chlorosis virus in Lebanon. Plant Dis. 90:378.

Accotto, G., Vaira, A., Vecchiati, M., Finetti Sialer, M., Gallitelli, D. and Davino, M. 2001. First report of Tomato chlorosis virus in Italy. Plant Dis. 85:1208.

Albuquerque, L. C., Varsani, A., Fernandes, F. R., Pinheiro, B., Martin, D. P., Ferreira, P. D. T. O., Lemos, T. O. and InoueNagata, A. K. 2012. Further characterization of tomatoinfecting begomoviruses in Brazil. Arch. Virol. 157:747-752.

Alvarez-Ruiz, P., Jimenez, C., Leyva-López, N. E. and MéndezLozano, J. 2007. First report of Tomato chlorosis virus infect- 
ing tomato crops in Sinaloa, Mexico. Plant Pathol. 56:1043.

Aranda, M. A., Fraile, A., Dopazo, J., Malpica, J. M. and GarcíaArenal, F. 1997. Contribution of mutation and RNA recombination to the evolution of a plant pathogenic RNA. J. Mol. Evol. 44:81-88.

Arruabarrena, A., Rubio, L., González-Arcos, M., Maeso, D., Fonseca, M. and Boiteux, L. 2015. First report of Tomato chlorosis virus infecting tomato crops in Uruguay. Plant Dis. 99:895.

Barbosa, J., Teixeira, A., Moreira, A., Camargo, L., Filho, A. B., Kitajima, E. and Rezende, J. 2008. First report of Tomato chlorosis virus infecting tomato crops in Brazil. Plant Dis. 92:1709.

Barbosa, J., Teixeira, L. and Rezende, J. 2010. First report on the susceptibility of sweet pepper crops to Tomato chlorosis virus in Brazil. Plant Dis. 94:374.

Barton, H. D., Rohani, P., Stallknecht, D. E., Brown, J. and Drake, J. M. 2014. Subtype diversity and reassortment potential for co-circulating avian influenza viruses at a diversity hot spot. J. Anim. Ecol. 83:566-575.

Bese, G., Bóka, K., Krizbai, L. and Takács, A. 2011. First report of Tomato chlorosis virus in tomato from Hungary. Plant Dis. 95:363.

Castro, R., Hernandez, E., Mora, F., Ramirez, P. and Hammond, R. 2009. First report of Tomato chlorosis virus in tomato in Costa Rica. Plant Dis. 93:970.

Çevik, B. and Erkıß, G. 2008. First report of Tomato chlorosis virus in Turkey. Plant Pathol. 57:767-767.

Dalmon, A., Bouyer, S., Cailly, M., Girard, M., Lecoq, H., Desbiez, C. and Jacquemond, M. 2005. First report of Tomato chlorosis virus and Tomato infectious chlorosis virus in tomato crops in France. Plant Dis. 89:1243.

Domingo, E. and Holland, J. J. 1994. Mutation rates and rapid evolution of RNA viruses. In: The evolutionary biology of viruses, ed. S. S. Morse, pp. 161-184. Raven Press, NY, USA.

Dovas, C., Katis, N. and Avgelis, A. 2002. Multiplex detection of criniviruses associated with epidemics of a yellowing disease of tomato in Greece. Plant Dis. 86:1345-1349.

Fiallo-Olivé, E., Hamed, A., Moriones, E. and Navas-Castillo, J. 2011. First report of Tomato chlorosis virus infecting tomato in Sudan. Plant Dis. 95:1592.

Font, M., Juárez, M., Martínez, O. and Jordá, C. 2004. Current status and newly discovered natural hosts of Tomato infectious chlorosis virus and Tomato chlorosis virus in Spain. Plant Dis. 88:82.

Fortes, I. M. and Navas-Castillo, J. 2012. Potato, an experimental and natural host of the crinivirus Tomato chlorosis virus. Eur. J. Plant Pathol. 134:81-86.

Fuller, T. L., Gilbert, M., Martin, V., Cappelle, J., Hosseini, P., Njabo, K. Y., Aziz, S. A., Xiao, X., Daszak, P. and Smith, T. B. 2013. Predicting hotspots for influenza virus reassortment. Emerg. Infect. Dis. 19:581-588.

Hanssen, I. M., Lapidot, M. and Thomma, B. P. 2010. Emerging viral diseases of tomato crops. Mol. Plant-Microbe Interact.
23:539-548

Hirota, T., Natsuaki, T., Murai, T., Nishigawa, H., Niibori, K., Goto, K., Hartono, S., Suastika, G. and Okuda, S. 2010. Yellowing disease of tomato caused by Tomato chlorosis virus newly recognized in Japan. J. Gen. Plant Pathol. 76:168-171.

Jacquemond, M., Verdin, E., Dalmon, A., Guilbaud, L. and Gognalons, P. 2009. Serological and molecular detection of Tomato chlorosis virus and Tomato infectious chlorosis virus in tomato. Plant Pathol. 58:210-220.

Johnson, M., Zaretskaya, I., Raytselis, Y., Merezhuk, Y., McGinnism, S. and Madden, T. L. 2008. NCBI BLAST: a better web interface. Nucleic Acids Res. 36:W5-W9.

Karasev, A. V. 2000. Genetic diversity and evolution of closteroviruses. Annu. Rev. Phytopathol. 38:293-324.

Kataya, A., Stavridou, E., Farhan, K. and Livieratos, I. 2008. Nucleotide sequence analysis and detection of a Greek isolate of Tomato chlorosis virus. Plant Pathol. 57:819-824.

Kearse, M., Moir, R., Wilson, A., Stones-Havas, S., Cheung, M., Sturrock, S., Buxton, S., Cooper, A., Markowitz, S. and Duran, C. 2012. Geneious Basic: an integrated and extendable desktop software platform for the organization and analysis of sequence data. Bioinformatics 28:1647-1649.

Kimura, M. 1980. A simple method for estimating evolutionary rates of base substitutions through comparative studies of nucleotide sequences. J. Mol. Evol. 16:111-120.

Lett, J., Hoareau, M., Reynaud, B., Saison, A., Hostachy, B., Lobin, K. and Benimadhu, S. 2009. First report of Tomato chlorosis virus in tomato on Mauritius Island. Plant Dis. 93:111.

Liu, H.-Y., Wisler, G. and Duffus, J. 2000. Particle lengths of whitefly-transmitted criniviruses. Plant Dis. 84:803-805.

Louro, D., Accotto, G. and Vaira, A. 2000. Occurrence and diagnosis of Tomato chlorosis virus in Portugal. Eur. J. Plant Pathol. 106:589-592.

Lozano, G., Moriones, E. and Navas-Castillo, J. 2004. First report of sweet pepper (Capsicum annuum) as a natural host plant for Tomato chlorosis virus. Plant Dis. 88:224.

Lozano, G., Moriones, E. and Navas-Castillo, J. 2006. Complete nucleotide sequence of the RNA2 of the crinivirus Tomato chlorosis virus. Arch. Virol. 151:581-587.

Marshall, N., Priyamvada, L., Ende, Z., Steel, J. and Lowen, A. C. 2013. Influenza virus reassortment occurs with high frequency in the absence of segment mismatch. PLoS Pathog. 9:e1003421.

Morris, J., Steel, E., Smith, P., Boonham, N., Spence, N. and Barker, I. 2006. Host range studies for Tomato chlorosis virus, and Cucumber vein yellowing virus transmitted by Bemisia tabaci (Gennadius). Eur. J. Plant Pathol. 114:265-273.

Nagy, P. D. 2008. Recombination in plant RNA viruses. In: Plant virus evolution, pp. 133-156, Springer.

Orílio, A. F., Fortes, I. M. and Navas-Castillo, J. 2014. Infectious cDNA clones of the crinivirus Tomato chlorosis virus are competent for systemic plant infection and whitefly-transmission. Virology 464:365-374.

Rozen, S. and Skaletsky, H. 2000. Primer3 on the WWW for gen- 
eral users and for biologist programmers. In: Bioinformatics Methods and Protocols. Methods in Molecular Biology ${ }^{T M}$, vol 132, eds. by S. Misener and S. A. Krawetz, Humana Press, Totowa, NJ.

Savory, F. R., Varma, V. and Ramakrishnan, U. 2014. Identifying geographic hot spots of reassortment in a multipartite plant virus. Evol. Appl. 7:569-579.

Segev, L., Wintermantel, W., Polston, J. and Lapidot, M. 2004. First report of Tomato chlorosis virus in Israel. Plant Dis. $88: 1160$.

Simon, A. and Bujarski, J. 1994. RNA-RNA recombination and evolution in virus-infected plants. Annu. Rev. Phytopathol. 32:337-362.

Solórzano-Morales, A., Barboza, N., Hernández, E., Mora-Umaña, F., Ramírez, P. and Hammond, R. 2011. Newly discovered natural hosts of Tomato chlorosis virus in Costa Rica. Plant Dis. 95:497.

Sundaraj, S., Srinivasan, R., Webster, C., Adkins, S., Perry, K. and Riley, D. 2011. First report of Tomato chlorosis virus infecting tomato in Georgia. Plant Dis. 95:881.

Tamura, K. and Nei, M. 1993. Estimation of the number of nucleotide substitutions in the control region of mitochondrial DNA in humans and chimpanzees. Mol. Biol. Evol. 10:512526.

Tamura, K., Stecher, G., Peterson, D., Filipski, A. and Kumar, S. 2013. MEGA6: molecular evolutionary genetics analysis version 6.0. Mol. Biol. Evol. 30:2725-2729.

Thekke-Veetil, T., Polashock, J. J., Marn, M. V., Plesko, I. M., Schilder, A. C., Keller, K. E., Martin, R. R. and Tzanetakis, I. E. 2015. Population structure of blueberry mosaic associated virus: Evidence of reassortment in geographically distinct isolates. Virus Res. 201:79-84.

Thompson, J. D., Gibson, T. and Higgins, D. G. 2002. Multiple sequence alignment using ClustalW and ClustalX. Curr. Protoc. Bioinformatics 2:2.3.

Trenado, H. P., Fortes, I. M., Louro, D. and Navas-Castillo, J. 2007. Physalis ixocarpa and P. peruviana, new natural hosts of Tomato chlorosis virus. Eur. J. Plant Pathol. 118:193-196.

Tsai, W., Shih, S., Green, S., Hanson, P. and Liu, H. 2004. First report of the occurrence of Tomato chlorosis virus and Tomato infectious chlorosis virus in Taiwan. Plant Dis. 88:311.

Vargas, J., Hammond, R., Hernández, E., Barboza, N., Mora, F. and Ramírez, P. 2011. First report of Tomato chlorosis virus infecting sweet pepper in Costa Rica. Plant Dis. 95:1482.

Vijaykrishna, D., Mukerji, R. and Smith, G. J. 2015. RNA virus reassortment: an evolutionary mechanism for host jumps and immune evasion. PLoS Pathog. 11:e1004902.

Wille, M., Robertson, G. J., Whitney, H., Bishop, M. A., Runstadler, J. A. and Lang, A. S. 2011. Extensive geographic mosaicism in avian influenza viruses from gulls in the northern hemisphere. PLoS One 6:e20664.

Wintermantel, W., Polston, J., Escudero, J. and Paoli, E. 2001. First report of Tomato chlorosis virus in Puerto Rico. Plant Dis. 85:228.

Wintermantel, W., Wisler, G., Anchieta, A., Liu, H.-Y., Karasev, A. and Tzanetakis, I. 2005. The complete nucleotide sequence and genome organization of Tomato chlorosis virus. Arch. Virol. 150:2287-2298.

Wintermantel, W. M. and Wisler, G. C. 2006. Vector specificity, host range, and genetic diversity of Tomato chlorosis virus. Plant Dis. 90:814-819.

Wisler, G., Duffus, J., Liu, H.-Y. and Li, R. 1998a. Ecology and epidemiology of whitefly-transmitted closteroviruses. Plant Dis. 82:270-280.

Wisler, G., Li, R., Liu, H.-Y., Lowry, D. and Duffus, J. 1998b. Tomato chlorosis virus: a new whitefly-transmitted, phloemlimited, bipartite closterovirus of tomato. Phytopathology 88:402-409.

Zhao, L.-M., Li, G., Gao, Y., Zhu, Y.-R., Liu, J. and Zhu, X.-P. 2015. Reverse transcription loop-mediated isothermal amplification assay for detecting Tomato chlorosis virus. J. Virol. Methods 213:93-97.

Zhao, L. M., Li, G., Gao, Y., Liu, Y. J., Sun, G. Z. and Zhu, X. P. 2014. Molecular detection and complete genome sequences of Tomato chlorosis virus isolates from infectious outbreaks in China. J. Phytopathol. 162:627-634.

Zhao, R., Wang, N., Wang, R., Chen, H., Shi, Y., Fan, Z. and Zhou, T. 2013a. Characterization and full genome sequence analysis of a Chinese isolate of Tomato chlorosis virus. Acta Virol. 58:92-94.

Zhao, R., Wang, R., Wang, N., Fan, Z., Zhou, T., Shi, Y. and Chai, M. 2013b. First Report of Tomato chlorosis virus in China. Plant Dis. 97:1123. 